\title{
Guaranteeing the Judgment of Civil Cases Within a Reasonable Time as a Requirement of the Right to a Fair Trial in Albania
}

\author{
Msc. Beslinda Rrugia \\ University "Aleksdandër Moisiu" Durrës \\ rrugiab@gmail.com \\ Msc. Bledar Biti \\ University "Aleksandër Moisiu" Durrës \\ avbiti@hotmail.com
}

Doi:10.5901/ajis.2014.v3n3p509

\begin{abstract}
Guaranteeing the fundamental rights and freedoms is one of the preconditions for the existence of the rule of law in a democratic society. Our paper tries to analyze how is the right to a fair trial guaranteed as far as it concerns the requirement that civil cases should be judged within a reasonable time. Compared to criminal law, civil law in Albania still lacks concrete time - limits within which the judgment of a civil case should necessarily end. The lack of such concrete time limits, is one of the principal causes for the delay of the civil judgments beyond a reasonable time, which represents itself a violation not only of the Constitution as a primary act regulating the fundamental rights in our country, but also of other conventional acts such as the European Convection of Human Rights, which enjoys a position of particular significance in Albanian Constitution compared to the other international acts that have been ratified in our country. Considering the fact that for the subjects of law the provision of justice within a reasonable time by the respective authorities, is considered almost as important as the right itself at that point that it is fair to affirm that "justice too long delayed is justice denied", we have found of particular interest to involve in our research also some possible suggestions on which are the types of measures we consider could be the most efficient to be taken in order to improve the judgment of civil cases within a reasonable time in our country.
\end{abstract}

Keywords: civil case, judgment within a reasonable time, European Court of Human Rights and Albanian Constitutional Court jurisprudence, default judgment, "Strasbourg Programme" of Turin's Court.

\section{The Constitution of the Republic of Albania and the ECHR}

The right to a fair trial is a constitutional right. ${ }^{1}$ Due process is one of individual rights associated with the regularity of an ordinary trial or an administrative process. ${ }^{2}$ So, "the meaning that the constitution has given to the protection of fundamental rights from public bodies through the fulfillment of legal proceedings, enables this right not to be reduced simply to a fair trial before then courts, but also to take a broader sense, that of a due process exercised even by other public bodies, which follow extra court procedures (administrative, parliamentary, arbitration or mediation procedures, etc.) ". 3

Also, since July of 1996, the year when the Parliament in Albania ratified the European Convention on Human Rights, this act is naturally considered as part of the legal system of our country. ${ }^{4}$ Article $6 / 1$ of European Convention on Human Rights guarantees the right to a fair trial as a fundamental right in a democratic society. ${ }^{5}$ The obligation to respect this right provided by the aforementioned convention applies to all public bodies, including not only the courts which are part of the judiciary system but also other bodies that implement their decisions. The protection of Article 6/1 extends over criminal charges as well as over rights and obligations of a civil nature.

In order for Article 6 to be applied in the civil context, there should be a "dispute" over a civil right. The Court interprets in a broad sense the concept of "civil rights and obligations". In the case Ringeisen against Austria (1971), the Court stated that Article 6/1 covers all those proceedings the result of which is decisive for private rights and obligations,

\footnotetext{
${ }^{1}$ Article 42 of the Constitution of the Republic of Albania

2 Vorpsi A., Due Process in the practice of the Constitutional Court of Albania, Maluka Publications, 2011

3 Omar L., A. Anastasi, Constitutional Law, Tirana, ABC Publisher, 2010

${ }^{4}$ Article 116 of the Constitution of the Republic of Albania

${ }^{5}$ Article 6/1 of the European Convention on Human Rights
} 
regardless of the character of the legislation that manages how the issue should be addressed, and regardless of the authority exercising the jurisdiction over the matter. ${ }^{6}$ The concept therefore, can be said to have an autonomous meaning as defined by the convention. What matters then is the kind of the right in question and whether the outcome of the proceedings would be "crucial to the rights and obligations of private character." 7

Civil matters under the convention are considered as follows: when the claim can be converted in money and stems from the violation of a civil right, regardless of the source of the conflict or of the jurisdiction of administrative courts; the right to protection of goodwill also is of civilian character, the same applies to the right to respect family life and to the state actions that affect its way of implementation which include decisions of placement of the child under foster care, the access that parents should have to the child, the child adoption and the placement in a substitute family; obligations are also civil in the sense of Article 6 when issues include incomes from social services, including social assistance, but also in case of the payment of insurance premiums; also procedures in matters of recognition of industrial property are intended as civil rights and obligations; the same applies to the conflicts between the owner and the tenant in connection with the contents of the lease agreement; or to the registrations on the list of lawyers; civil rights are also considered the right to personal freedom and other rights of a similar nature. ${ }^{8}$

Some of these issues as those related to the rights and obligations to respect for family life, issues related to the incomes earned by social services or pension payments are considered of special priority as far as regards their need to be judged within a reasonable time.

\title{
2. The Judgment of Civil Cases within a Reasonable Time
}

The concept of "judgment within a reasonable time" for civil matters as provided by the European Convention on Human Rights and also by the Constitution of the Republic of Albania is of fundamental importance in providing the necessary guarantees to the parties in legal proceedings against long and unjustified procedural delays. The judgment of civil matters within a reasonable time is also important for guaranteeing - especially to subjects that have a particular situation - that within a reasonable time and through a court decision an end will be put to legal uncertainty.

To assess whether a civil case is resolved within a reasonable time it should be clear when did the proceeding start and when did it end.

In the analysis of civil proceedings in the district courts in Albania in 2013, the OSCE Presence argues that:

\begin{abstract}
... "In civil cases, the calculation starts from the moment when the matter is referred to the competent judicial authority.9 When there is a need to initially submit a request to an administrative authority, the duration of the trial is calculated by beginning from the moment of submission of the request.10 The trial is considered complete when the final decision is taken.11 In some cases, the European Convention on Human Rights may also include within this term the enforcing procedures and other forms of execution of the judgments.12 It is worth noting that in order to determine if there has been a violation of the right to trial within a reasonable time, as Article 6 of the European Convention on Human Rights provides, it is sufficient to show that the applicant has suffered a harm or has been adversely affected by the delays of procedures. ${ }^{13} \ldots$ ".
\end{abstract}

The European Court of human rights has developed four main criteria in order to assess whether the duration of

\footnotetext{
${ }^{6}$ Gomien D., Short Guide to the European Convention on Human Rights, Strasburg, 2005

7 See Baraona v Portugal, 1987

${ }^{8}$ M. A. Nowicki, On the European Convention - A short commentary to the ECHR-Zakamycze, Krakow, Albanian edition: The Albanian Center for Human Rights Publications, Tirana, 2000

${ }_{9}$ See Scopelliti v Italy, ECtHR, 23 November 1993, paragraph 18, and Deweer v. Belgium, ECtHR, 27 Feb. 1980, quoted in the OSCE Presence in Albania, Towards justice, civil process analysis in the district courts, 2013.

10 See Jorg and others v. Portugal, ECtHR, 19 February 2004, paragraph 30, citing the OSCE Presence in Albania, Towards justice, civil process analysis in the district courts, 2013

${ }_{11}$ See Deweer v. Belgium, ECtHR, 27 February 1980, paragraph 46, citing the OSCE Presence in Albania, Towards justice, civil process analysis in the district courts, 2013.

12 See Scordino v. Italy, ECtHR judgment of the Grand Chamber (Grand Chamber), 29 March 2006, paragraph 197, Jankovic against Croatia, ECtHR, March 5, 2009, paragraph 68; Hornsby v. Greece, ECtHR, 1 April 1998, paragraph 40; Plazonić against Croatia, ECtHR, March 6, 2008, cited in paragraph 47 of the OSCE Presence in Albania, Towards justice, civil process analysis in the district courts, 2013.

${ }^{13}$ See Jorge Nina Jorge and Others v. Portugal, ECtHR, 19 Feb. 2004, quoted in the OSCE Presence in Albania, Towards Justice, Analysis of the civil process in district courts, 2013.
} 
proceedings in a given case has been reasonable. These four criteria are as follows:

- The complexity of the case: The factors which determine if a case should be considered complex may be the number of witnesses or expert witnesses, the volume of evidence to be examined, the number of the accused persons, the difficulties of the legal issues rising from the case or the intervention by other persons. ${ }^{14}$ The court examines case by case whether the complexity of the case justifies the length of proceedings. The more a case is considered as complex, the more the Court allows for protracted proceedings.

- The conduct of the claimant: The factors which determine if the duration of a trial can be imputed to the claimant are: has the claimant followed the summons or not, has paid the court fees, whether he complied with his promise to submit documents. However, the applicant cannot be blamed for making full use of the remedies available to him under domestic law ${ }^{15}$. An "applicant's behavior constitutes an objective fact which cannot be attributed to the respondent state and which must be taken into account for the purpose of determining whether or not the reasonable time referred to in Art. 6 paragraph 1 of the European Convention on Human Rights has been exceeded" 16 .

However it is important to underline that the delays caused by the applicant are only one factor which the Court takes into account when assesses whether the duration of the proceedings can be considered a reasonable one. The Court can still find a violation of art. 6 if some of the delays are attributable to the applicant, but are outweighed by delays which the respondent state has caused ${ }^{17}$.

- The conduct of the respondent state: another criteria the Court applies is how much the duration of the proceedings can be imputed to the respondent state. In that respect, the Court gives special attention to the periods of inactivity ${ }^{18}$. The question, whether the length of proceedings is attributable to the state is not to be confused with the question of responsibility of the individual judge for delays. Even if the judge who is handling the case is overburdened, this cannot justify extremely long procedures. The state is under an obligation to organize its legal system in such a way that the courts can guarantee everyone's right to obtain a final decision within a reasonable time ${ }^{19}$. The enjoyment of the right to a trial within reasonable time must be secured by the authorities through all appropriate means, including changing the jurisprudence or through legislative measures if necessary ${ }^{20}$. Moreover if hearings have to be postponed several times due to the absence of the witnesses, the responsibility of the state is engaged if the court handling the case does not avail itself of all measures available under domestic law. ${ }^{21}$ The burden to facilitate speedy proceedings is on the state even in legal systems in which the procedural initiative lies with the parties ${ }^{22}$.

- Importance of the matter to the applicant: In the frame of this criteria, the Court considers what is at stake for the applicant. If the outcome of the procedure is particularly important for the applicant, even shorter durations of proceedings may lead to a violation. The Court has held that certain matters call for special expediency, for example pension disputes, litigation regarding the custody for children, disputes regarding civil status and capacity, pre-trial detention cases and cases regarding the compensation for the victims of road accidents. The high age of the applicant may be another factor which calls for swift proceedings ${ }^{23}$.

The Code of Civil Procedure in our courts recognizes the obligation to conduct a trial within a reasonable time. ${ }^{24}$ However, neither the code nor any other law in the formal sense (ie, approved by the Parliament) does not define which terms specifically are considered reasonable. Also, the rules of civil procedure, unlike criminal proceedings do not determine maximum limits of time between sessions. ${ }^{25}$ The Code of Civil Procedure stipulates that it is the court itself which sets the hearings and the deadlines within which procedural acts and other actions should be performed. In this sense judges must manage responsibly judicial time in order to fulfill the constitutional obligation to conduct a judgment within a reasonable time. The OSCE Presence in Albania by observing civil proceedings in several court districts found

\footnotetext{
14 See Van Dijk et al., Theory and Practice of the European Convention on Human Rights, 4 th edition

15 See Girardi v Austria (application no. 500064/99), judgment of 11 December 2003, para 55

${ }_{16}$ See Erkner and Hofauer v Austria (application no. 9616/81), judgment of 24 March 1987, para 69

17 See Sumerli v Germany (Grand Chamber) (application no. 75529/01), judgment of 8 June 2006

18 See Vachev v Bulgaria (application no. 42987/98), judgment of 8 July 2004, para 96

19 See Surmeli v Germany (application no. 75529/01), judgment of 8 June 2006, para 129

20 See Kitov v Bulgaria (application no. 37104/97), judgment of 3 April 2003, para 73

${ }^{21}$ See Kusmierek v Poland (application no. 10675/02), judgment of 21 September 2004, para 65

22 See Surmeli v Germany (Grand Chamber) (application no. 75529/01), judgment of 8 June 2006, para 129

${ }^{23}$ See Sussmann v Germany (Grand Chamber) (application no. 20024/92), judgment of 31 August 1996, para 61

${ }^{24}$ See Article 28 of the Code of Civil Procedure

${ }^{25}$ See Article 342 of the Code of Criminal Procedure
} 
that "the current practice of the courts shows that judges rarely manage actively judicial proceedings."26 Thus in this analysis it is highlighted that the judges do not always plan in advance sessions in consultation with representatives of the parties, on the other hand the parties do not present all their evidence at the earliest opportunity, which constitutes one of the most common causes of delays. Even the current system of the preparatory phase in judicial proceedings where actions are performed only in physical sessions verbally, is noted to cause enough delays compared with those systems where the preparatory phase is a written one and helps to reduce the number of trials and the duration of processes avoiding therefore a significant number of unproductive sessions. Problems were found with the summoning of parties and of witnesses involved, other problems arise from the failure of participants to take place in the hearings without any reason, as well as from delays in providing reasoned decisions. ${ }^{27}$

Although there is no law in the formal sense, the High Council of Justice has directed the courts regarding procedural deadlines for certain types of civil matters. ${ }^{28}$ But these guidelines, in order to be applied with greater responsibility by judges, should be taken into account when the High Council of Justice estimates the judges for their promotion and transfer. ${ }^{29}$

However the determination of these terms from the High Council of Justice, does not deflect neither the responsibility of the Parliament to pass a law which establishes specific deadlines for court proceedings, nor the responsibility of the courts and judges who menage court proceedings taking into account the jurisprudence of the European Court of Human Rights, which is legally binding for them as long as our country has ratified the European Convention of Human Rights and as long as the European Court of Human Rights is considered a living mechanism which through its reasoned decisions develops and gives meaning to the provisions of the Convention itself, including the obligations arising from Article 6/1.

As far as the role of the judges in judging civil proceedings within a reasonable time is concerned, the Turin tribunal launched a successful experimental programme ("the Strasbourg Programme") aimed at introducing new working methods in the internal organization of the tribunal in order to identify and prioritize old, pending cases and avoid unnecessary delays.30

Back in the context of the due process of law, of particular importance is "The 22nd Recommendation of the OSCE Presence: Setting Automatic Judgment for the respondent unjustifiably absent", ${ }^{11}$ which is directly related to one of the elements (conduct of the parties) which is analyzed to assess whether the right to a trial within a reasonable time is taken into account or not."

Automatic judgment or (the default judgment) means that the court can decide regarding the issue in favor of the other party present if the other party is absent without a legitimate reason. ${ }^{32}$ The inclusion of automatic judgment by the Code of Civil Procedure, is legitimized by reasoning first in an expansion of the party autonomy, ie. the right of a party to settle the dispute by agreeing up with the other party ${ }^{33}$ and second the unjustified absence can be seen as an implicit admission of the other party's claim. ${ }^{34}$

Also the inclusion in the Code of Civil Procedure of the Republic of Albania of automatic judgment can be conceived as a sanction against parties involved in the process who are unjustifiably absent, causing delays in judicial proceedings.

As a result of the inclusion of automatic judgments in the Civil Procedure Code we will have the elimination of costly court proceedings and the disciplining of the parties involved in those proceedings, enabling at the same time the observance of the right to a trial within a reasonable time.

\footnotetext{
26 OSCE Presence in Albania, Towards justice, civil process analysis in the district courts, 2013.

27 OSCE Presence in Albania, Towards justice, civil process analysis in the district courts, 2013.

${ }^{28}$ Decision of the High Council of Justice no. 199/3, dated September 15, 2006 "On the criteria of evaluation of judicial activity", point 5 b - e. Timing of first degree trial: Trials of commercial disputes - a maximum of 6 months. Trials of family disputes - maximum 4 months. Trials of administrative disputes - maximum 1 month. Trials of civil disputes general character maximum 6 months. These time limits are used when evaluating the work of judges. Deadlines begin as of the registration of the case in the court.

${ }^{29}$ OSCE Presence in Albania, Towards justice, civil process analysis in the district courts, 2013.

30 https://wcd.coe.int/ViewDoc.jsp?id=1378699\&Site=CM\#P217_29380

31 OSCE Presence in Albania, Towards justice, civil process analysis in the district courts, 2013.

32 OSCE Presence in Albania, Towards justice, civil process analysis in the district courts, 2013.

33 See, Jo Hov Rettergang III Sivilprosess, Papinian, Oslo 2000

${ }^{34}$ OSCE Presence in Albania, Towards justice, civil process analysis in the district courts, 2013.
} 


\section{The Role of the European Court of Human Rights on Constitutional Court Judgments in Albania Regarding the Right for a Fair Trial}

The Constitution of the Republic of Albania in Article 42 is not exhaustive in terms of giving a detailed understanding of the concept of due process of law. But the practice of the Constitutional Court, also directed by the jurisprudence of the European Court of Human Rights, is trying to hold one more this concept and explore issues related to specific elements of the due process of law. Moreover we recall the decision given by the Court to the case Marini v. Albania where the European Court of Human Rights notes that: "... according to Article 6 of the Convention, everyone has the right to be provided within a reasonable time a final judgment concerning the determination of his civil rights and obligations. " Also, the European Court of Human Rights stresses that it is a duty of The High Contracting Parties to organize their legal systems in such a way as to enable the court to meet this requirement. ${ }^{35}$ So the states have the obligation to take all the measures in order to fulfill the obligations assumed by ratifying the convention. These measures could include legislative measures when such a thing is necessary or fitting the jurisprudence of the domestic courts to the European Court of Human Rights jurisprudence noting that the latter one is also an obligation. ${ }^{36}$

We deal here with two moments that already constitute a jurisprudence for the Albanian constitutional court decisions as a result of the pursuing the reasoning of the decisions taken by the European Court of Human Rights: first the non obligation for exhausting all legal remedies as far as violations of the right to a fair trial - in particular of the right to guarantee the judgment of civil cases within a reasonable time - is concerned and secondly the involvement of the execution phase as a part of the due process of law.

As provided by the Constitution, in Albania individuals may address to the Constitutional Court only through a conditioned request for issues that concern the right to a fair trial - including violations of this right due to delays in the judgment of civil cases within a reasonable time..$^{37}$ Thus, the control of the Constitutional Court is limited to a procedural control of the elements that constitute the legal process, part of which is the right for civil proceedings to be judged within a reasonable time, without focusing even on the right claimed - a kind of inspection reserved only to the judiciary in our country.

Formally, the constitution provides some conditions - among which the requirement of exhaustion of "all other remedies" before filing an individual lawsuit in the constitutional court. If this condition is not met formally, a panel composed of three members from the Constitutional Court may decide not to pass the case to a court hearing. ${ }^{38}$

The constitutional complaint is conceived as an auxiliar or additional (subsidiary) mean, in addition to other legal means, this is why it can be exercised only after the exhaustion of all other remedies provided by law in order to gain a right. But the law researcher Arta Vorpsi rightly raises two very important questions regarding this issue:

\footnotetext{
"...Should the exhaustion of all other legal remedies be necessarily required by the Constitutional Court even in the case when the plaintiff relies his claim precisely on the lack of the possibility of exhausting those means, because the courts do not act in accordance with the constitutional standards that require that the judgment of civil cases should be done within a reasonable time?

Such a thing seems to lose the essence of the claimant's right because once the litigation has ended it is impossible to reestablish that right... "39
}

Actually, the Albanian legal system lacks a specific legal mean which could be used by individuals to seek the restoration for the excessive delay of court proceedings. This has been more than once stressed from the European Court of Human Rights in previous cases against Albania - such as Gjonbocari v. Albania, Marini v. Albania etc.

The Constitutional Court, in respect of article 17 of the Constitution and of article 5 of the Law N. 8137, dated 31.07.1996 "On the Ratification of the European Convention for the Protection of Human Rights and Fundamental Freedoms" as far as regarding the claim that the complaint should not be accepted because the legal remedies are not exhausted determines that:

\footnotetext{
${ }^{35}$ See Marini v Albania, date 7.7.2008, application Nr.3738/02, par. 154

${ }^{36}$ Article 5 of the Law N.8137, date 31.7.1996 "On the Ratification of the European Convention for the Protection of Human Rights and Fundamental Freedoms"

${ }^{37}$ Article 131/f, 134/1/g and article 134/2 of the Constitution of the Republic of Albania

${ }^{38}$ Articles 30, 31 of the Law Nr. 8577, dt.10.2.2000 "On the organization and functioning of the Constitutional Court of the Republic of Albania"

${ }^{39}$ Vorpsi A., Due Process in the practice of the Constitutional Court of Albania, Maluka Publications, 2011
} 
"...the claims of individuals for violations of the right to a trial within a reasonable time may be judged by this court, regardless of the fact that the trial for the protection of their rights, their freedoms and constitutional or legal matters has not yet been completed in all instances of the courts of ordinary jurisdiction ... "40

This kind of reasoning is also used in other similar decisions of the Constitutional Court which has embraced the European Court of Human Rights' jurisprudence concerning this issue. ${ }^{41}$

The practice of the European Court of Human Rights has played a positive role in the jurisprudence of our Constitutional Court even when it compelled our Constitutional Court to consider the non - execution of court decisions as a part of the due process of law, which until 2005 was not considered as such by the Constitutional Court. ${ }^{42}$ In Qufaj v. Albania, the Strasbourg Court notes that "the Albanian legal system provides for an adjustment in the form of a complaint regarding violations of the right to a fair trial." Below this the European Court of Human Rights emphasizes that:

"...the provisions regarding the due process of law in Albania should have been interpreted in a way such as to guarantee an effective remedy for the alleged breach of Article 6/1 of the Convention, therefore the court gave the opinion that the Constitutional Court was competent to examine the claim of the company about the non execution of a final decision, as part of its own jurisdiction concerning its right to ensure the right to a fair trial for individuals." 43

Today there is an ample practice concerning the decisions of the Constitutional Court for breaches of the right to a due process of law during the execution phase. However it still remains problematic the fact that the decision of the Constitutional Court ascertaining the infringement is another final and binding decision to the plaintiff, but that does not set for them compensations or other commandments.

This has thrown into question the effectiveness of the decisions of the Constitutional Court, which is concluded by the European Court of Human Rights in its jurisprudence with the Albanian state as party. According to Article 13 of the European Convention on Human Rights, a remedy will be considered effective: if it nationally guarantees the existence of a mean to enforce the essence of the right, when it specifically and explicitly defines the competent authority for the concrete breach and very important when it provides the possibility to reestablish the violated right.

The constitutional court's decision as long as it neither regulates the consequences of the issue that has been judging nor provides compensations to the injured party cannot be considered completely an effective tool in itself. For this reason our country should consider the possibility of changing the legislation in order that the violations found by the constitutional court could be repaired within the system and in the shortest time but most of all the Constitutional Court should proceed at least in a parallel way with European Court of Human Rights' jurisprudence in reasoning its decisions (such as expanding the traditional competence of the Constitutional Court determining compensations for the party that has been harmed, etc.).

\section{Conclusions}

The Albanian Constitution, the European Convention of Human Rights, and the Code of Civil Procedure recognize the obligation for our courts to conduct a trial within a reasonable time. However, neither the Albanian Constitution, neither the European Convention of Human Rights nor the Civil Procedure Code or any other law in a formal sense (ie, approved by the Parliament) does not define which term is specifically considered reasonable. Also, the rules of procedure in civil matters, unlike criminal proceedings do not determine the maximum limits of time between sessions. The Civil Procedure Code stipulates that it is the court which sets hearings and deadlines within which procedural acts are performed. In this sense judges must manage responsibly judicial time in order to fulfill the constitutional obligation to ensure judgment of civil cases within a reasonable time.

Although there is not a law in the formal sense, the High Council of Justice has directed the courts regarding procedural deadlines for certain types of civil matters. But these guidelines of the High Council of Justice should be taken into account when the High Council of Justice estimates judges for promotion and transfer in order for these guidelines to be applied with responsibility by judges.

However the determination of concrete time limits by the High Council of Justice, does not deflect the responsibility of the Parliament to approve a law in order to establish specific deadlines for civil judicial proceedings, but also the

\footnotetext{
40 Decision of the Constitutional Court Decision no. 12, dated 05.03.2012

${ }^{41}$ Decision of the Constitutional Court Decision no.35, dated 17.07.2013

42 See Qufaj v Albania, 18 september 2004

43 Vorpsi A., Due Process in the practice of the Constitutional Court of Albania, Maluka Publications, 2011
} 
responsibility of the courts and judges to respect the ECHR jurisprudence, which constitutes an obligation to be respected as far as our country has ratified the ECHR and as far as this instrument constitutes a living mechanism which through reasoned decisions develops and gives meaning to its provisions, including to the obligations arising from Article $6 / 1$ of the Convention.

\section{References}

The Constitution of the Republic of Albania;

The Code of Civil Procedure of the Republic of Albania;

The Code of Criminal Procedure of the Republic of Albania;

Vorpsi A., Due Process in the practice of the Constitutional Court of Albania, Maluka Publications, 2011;

Omar L., A. Anastasi, Constitutional Law, Tirana, ABC Publisher, 2010;The European Convention on Human Rights;

Gomien D., Short Guide to the European Convention on Human Rights, Strasburg, 2005;

M. A. Nowicki, On the European Convention - A short commentary to the ECHR- Zakamycze, Krakow, Albanian edition: The Albanian Center for Human Rights Publications, Tirana, 2000;

Baraona v Portugal, 1987;

Scopelliti v Italy, ECtHR, 23 November 1993, paragraph 18, and Deweer v. Belgium, ECtHR, 27 Feb. 1980, quoted in the OSCE Presence in Albania, Towards justice, civil process analysis in the district courts, 2013;

Jorg and others v. Portugal, ECtHR, 19 February 2004, paragraph 30, citing the OSCE Presence in Albania, Towards justice, civil process analysis in the district courts, 2013;

Deweer v. Belgium, ECtHR, 27 February 1980, paragraph 46, citing the OSCE Presence in Albania, Towards justice, civil process analysis in the district courts, 2013;

Scordino v. Italy, ECtHR judgment of the Grand Chamber (Grand Chamber), 29 March 2006, paragraph 197, Jankovic against Croatia, ECtHR, March 5, 2009, paragraph 68; Hornsby v. Greece, ECtHR, 1 April 1998, paragraph 40; Plazonić against Croatia, ECtHR, March 6, 2008, cited in paragraph 47 of the OSCE Presence in Albania, Towards justice, civil process analysis in the district courts, 2013;

Jorge Nina Jorge and Others v. Portugal, ECtHR, 19 Feb. 2004, quoted in the OSCE Presence in Albania, Towards Justice, Analysis of the civil process in district courts, 2013;

Van Dijk et al., Theory and Practice of the European Convention on Human Rights, 4 th edition;

Girardi v Austria (application no. 500064/99), judgment of 11 December 2003, ;

Erkner and Hofauer v Austria (application no. 9616/81), judgment of 24 March 1987;

Sumerli v Germany (Grand Chamber) (application no. 75529/01), judgment of 8 June 2006;

Vachev v Bulgaria (application no. 42987/98), judgment of 8 July 2004;

Kitov v Bulgaria (application no. 37104/97), judgment of 3 April 2003;

Kusmierek v Poland (application no. 10675/02), judgment of 21 September 2004;

Sussmann v Germany (Grand Chamber) (application no. 20024/92), judgment of 31 August 1996;

OSCE Presence in Albania, Towards justice, civil process analysis in the district courts, 2013; Decision of the High Council of Justice no. 199/3, dated September 15, 2006 "On the criteria of evaluation of judicial activity", point 5 b - e. Timing of first degree trial: Trials of commercial disputes - a maximum of 6 months. Trials of family disputes - maximum 4 months. Trials of administrative disputes - maximum 1 month. Trials of civil disputes general character maximum 6 months. These time limits are used when evaluating the work of judges. Deadlines begin as of the registration of the case in the court;

Jo Hov Rettergang III Sivilprosess, Papinian, Oslo 2000;

Marini v Albania, date 7.7.2008, application Nr.3738/02,;

The Law N.8137, date 31.7.1996 "On the Ratification of the European Convention for the Protection of Human Rights and Fundamental Freedoms";

The Law Nr. 8577, dt.10.2.2000 "On the organization and functioning of the Constitutional Court of the Republic of Albania";

Decision of the Constitutional Court Decision no. 12, dated 05.03.2012

Qufaj v Albania, 18 september 2004; https://wcd.coe.int/ViewDoc.jsp?id=1378699\&Site=CM\#P217_29380; 